\title{
Kadar Kolesterol dan Vitamin A pada Telur Itik Pengging, Itik Tegal dan Itik Magelang
}

\section{The Cholesterol Level and Vitamin A on Egg of Pengging Duck, Tegal Duck, and Magelang Duck}

\author{
Ririn Khairin Nisa ${ }^{1}$, Tyas Rini Saraswati ${ }^{2}$, Enny Yusuf Wachidah Yuniwarti ${ }^{2}$ \\ ${ }^{1}$ Program Studi Biologi, Departemen Biologi, Fakultas Sains dan Matematika, Universitas Diponegoro \\ ${ }^{2}$ Departemen Biologi, Fakultas Sains dan Matematika, Universitas Diponegoro \\ Jl. Prof. Soedarto, SH, Tembalang, Semarang \\ *Email : tyasrinis63@gmail.com
}

Diterima 28 Agustus 2015 / Disetujui 28 Agustsus 2017

\begin{abstract}
ABSTRAK
Penelitian ini bertujuan untuk mengetahui kadar kolesterol dan vitamin A dalam telur itik Pengging, itik Tegal, dan itik Magelang. Seleksi sampel telur itik Pengging, itik Tegal, dan itik Magelang dilakukan di Balai Pembibitan dan Budidaya Ternak Non Ruminansia (BPBTNR). Parameter yang diamati adalah kadar kolesterol dan vitamin A dalam telur. Data yang diperoleh dianalisis menggunakan rancangan acak lengkap (RAL), dengan 3 perlakuan yaitu itik Pengging, itik Magelang, dan itik Tegal dan 3 ulangan. Jika ada perbedaan antar perlakuan maka dilanjutkan dengan uji lanjut menggunakan uji Duncan pada taraf kepercayaan 95\%. Hasil penelitian menunjukkan bahwa terdapat perbedaan nyata terhadap kadar kolesterol dan vitamin A pada telur itik Pengging dengan itik Tegal. Hasil yang sama juga terlihat yaitu perbedaan antara itik Magelang dengan itik Tegal, di sisi lain, itik Pengging dan itik Magelang tidak terlihat perbedaan yang nyata. Berdasarkan hasil tersebut, maka dapat disimpulkan bahwa telur itik Tegal baik untuk dikonsumsi karena mempunyai kadar kolesterol lebih rendah.
\end{abstract}

Kata kunci: kolesterol, vitamin A, telur Itik

\begin{abstract}
The study aimed to determine the levels of cholesterol and vitamin A from Pengging ducks, Tegal ducks, and Magelang ducks eggs. Sample selection of those eggs performed at Balai Pembibitan dan Budidaya Ternak Non Ruminansia (BPBTNR). Parameters measured were cholesterol and vitamin A contained in eggs. Data obtained were analyzed through a basic test completely randomized design (CRD) with three treatments which were Pengging duck, Magelang duck, Tegal duck and three repetitions. If there were a difference between treatments then followed by a further with Duncan test at a significance level of $95 \%$. The result showed that there were a significant different of the levels of cholesterol and vitamin A contained in the egg between Pengging ducks and Tegal ducks. The same results also showed which is the different between Magelang ducks and Tegal ducks. On the other side, there was insignificant different between Pengging ducks and Magelang ducks. Based on the results, it can be concluded that Tegal duck good to be consumed due to a lower level of cholesterol.
\end{abstract}

keywords : cholesterol, vitamin A, duck egg

\section{PENDAHULUAN}

Telur adalah salah satu bahan makanan hewani yang dikonsumsi selain daging, ikan, dan susu. Umumnya telur yang dikonsumsi berasal dari jenis-jenis unggas, seperti ayam, angsa, dan itik. Telur itik yang berada di Daerah Jawa dihasilkan dari itik petelur yang unggul. Populasi itik ternak menyebar di Jawa Tengah, Jawa barat, dan Jawa Timur (Sudaryani, 2003).

Beberapa jenis itik lokal yang berkembang di Indonesia, antara lain itik Alabio, itik Magelang, itik Mojosari, itik Pengging, itik Tegal, itik Bali, dan lain-lain. Masing-masing jenis itik tersebut 
diberi nama sesuai dengan daerah utama tempat budidaya (Suparyanto, 2005). Itik lokal Indonesia hampir seluruhnya merupakan keturunan bangsa itik Indian Runner. Akibat domestikasi, terbentuklah beberapa varian seperti besar tubuh, konformasi, dan warna bulu, yang dikenal sebagai Anas domesticus (Bappenas, 2009).

Murtidjo (2002) melaporkan secara umum itik mulai bertelur pada umur 6 bulan dan terus bereproduksi hingga umur 2 tahun, dan kemudian setelah umur 2 tahun diafkir sebagai itik pedaging. Telur kaya akan nutrisi. Telur itik mengandung kuning telur lebih banyak dan putih telur relatif sedikit. Perbedaan komposisi kimiawi telur dipengaruhi oleh faktor genetik, pakan, dan umur (Poedjiadi dan Supriyanti, 2005).

Perbedaan kadar kolesterol dan vitamin A karena adanya perbedaan potensi metabolik dengan konsumsi pakan. Sumber kolesterol ada 2, yaitu kolesterol endogen dan eksogen yang terdapat dalam bahan pakan. Kritchevsky (2006) melaporkan, kandungan kolesterol dan vitamin A pada telur itik bergantung dari nutrisi pakan yang dikonsumsinya. Kolesterol dalam telur merupakan bagian dari kuning telur. Produksi kuning telur terjadi di hati dan distimulasi oleh estrogen. Prekursor kuning telur kemudian ditranspor dari hati lewat darah menuju ke folikel ovarium. Komponen kuning telur sekitar $65 \%$ adalah lipoprotein kompleks. Lipid kuning telur terdiri atas $70-75 \%$ trigliserida, $20-25 \%$ fospolipid, dan $40 \%$ adalah kolesterol. Kolesterol pada itik dan angsa lebih tinggi daripada kadar kolesterol pada ayam (Safitri, 2007).

Kolesterol merupakan prekursor dari semua hormon steroid dan asam empedu serta komponen dari membran plasma. Hati adalah organ utama dari metabolisme kolesterol, umumnya menunjukkan respons terbesar terhadap makanan yang mengandung kolesterol. $\quad \beta$-karoten merupakan bentuk provitamin A paling aktif, yang terdiri atas dua molekul retinol yang saling berkaitan, salah satu produk hewani yang kaya akan $\beta$-karoten adalah kuning telur (Azrimaidaliza, 2007). Vitamin A dalam telur berasal dari suatu pigmen yang berasal dari tanaman maupun hewan yang merupakan prekursor vitamin A. Vitamin adalah zat gizi yang dibutuhkan sebagai katalis dalam proses pembentukan atau pemecahan zat gizi lain di dalam tubuh, jadi hanya dibutuhkan dalam jumlah sedikit. Vitamin A pada telur itik berperan penting dalam mengatur fungsi penglihatan dan menjaga kesehatan mata, membantu pertumbuhan dan meningkatkan sistem imunitas (Kritchevsky, 2006).

\section{METODE PENELITIAN}

Penelitian ini menggunakan Rancangan Acak Lengkap (RAL) dengan 3 perlakuan yaitu telur itik Pengging, itik Magelang, dan itik Tegal dan 3 ulangan. Seleksi sampel telur itik Pengging, itik Tegal, dan itik Magelang dilakukan di Balai Pembibitan dan Budidaya Ternak Non Ruminansia (BPBTNR). Masing-masing daerah diambil sampel 3 butir telur. Telur yang didapat dibersihkan dan diberi tanda sesuai daerah. Parameter yang diamati adalah analisis vitamin A dan analisis kadar kolesterol pada telur

- Analisis vitamin A (Nielsen, 2010).

Analisis Kandungan Vitamin A sebagai $\beta$ karoten dengan Spektrofotometer UV-Vis

- Kadar Kolesterol

Penentuan Kadar Kolesterol (metode Liebermann Burchard )

Data dianalisis dengan Anova. Apabila hasil analisis menunjukkan berbeda nyata maka dilanjutkan dengan uji lanjut, yaitu menggunakan uji jarak berganda Duncan pada taraf kepercayaan 95\% (Montgomery, 2006).

\section{HASIL DAN PEMBAHASAN}

Hasil analisis menunjukkan terdapat perbedaan nyata antara kadar kolesterol telur itik Pengging dengan itik Tegal, itik Magelang dengan itik Tegal, sedangkan kadar kolesterol telur itik Pengging dan itik Magelang tidak berbeda nyata. Perbedaan pada kadar kolesterol telur tersebut diduga karena adanya perbedaan potensi metabolik ditunjukkan dengan konsumsi pakan dan komposisi pakan tidak berbeda, tetapi ada perbedaan berat kuning telur ketiga itik tersebut. Sumber kolesterol ada 2, yaitu kolesterol endogen yang dibuat di dalam sel tubuh terutama hati, oleh 
karena itu tinggi dan rendahnya kolesterol dalam tubuh dipengaruhi oleh kecepatan sintesis kolesterol di dalam tubuh dan eksogen yang terdapat dalam bahan pakan. Guyton (2007) menjelaskan bahwa peningkatan kadar kolesterol kuning telur juga dapat terjadi karena pembentukan kolesterol endogen. Pakan yang diserap di usus mengandung komponen antara lain karbohidrat, lemak, protein, dan lain-lain. Zat-zat tersebut dipecah menjadi senyawa yang lebih sederhana kemudian melewati vena porta hepatika atau sistem limfatik menuju ke hati, kemudian diubah menjadi asetil KoA. Seluruh reaksi skualen menjadi kolesterol berlangsung dalam retikulum endoplasma. Pengangkutan asam lemak dan kolesterol dari hati ke seluruh tubuh dalam bentuk lipoprotein (endogenus), kemudian di hati, asam lemak diresintesis menjadi trigliserida yang kemudian bergabung dengan kolesterol, fosfolipid, dan protein menjadi very low density lipoprotein (VLDL) yang akan diangkut ke seluruh jaringan tubuh termasuk ke folikel ovarium, sehingga dengan adanya peningkatan kolesterol endogen dan salah satunya tersalur ke folikel ovarium akan menjadikan kadar kolesterol telur lebih tinggi.

Tabel 1. Hasil Analisis Kadar Kolesterol Telur, Vitamin A pada Telur, Berat Kuning Telur, dan Konsumsi Pakan dari Itik Pengging, Itik Magelang, dan Itik Tegal.

\begin{tabular}{lccc}
\hline \multicolumn{1}{c}{ Parameter } & Itik Pengging & Itik Magelang & Itik Tegal \\
\hline $\begin{array}{l}\text { Kadar kolesterol telur } \\
(100 / \mathrm{mg})\end{array}$ & $921.57^{\mathrm{a}} \pm 19.44$ & $913.28^{\mathrm{a}} \pm 24.26$ & $827.81^{\mathrm{b}} \pm 14.14$ \\
$\begin{array}{l}\text { Kadar vitamin A telur } \\
(100 / \mathrm{mg})\end{array}$ & $415.61^{\mathrm{a}} \pm 13.51$ & $395.49^{\mathrm{a}} \pm 25.95$ & $346.46^{\mathrm{b}} \pm 22.19$ \\
Berat kuning telur $(\mathrm{g})$ & $22.5^{\mathrm{b}} \pm 3.12$ & $25.867^{\mathrm{a}} \pm 3.95$ & $19.4^{\mathrm{c}} \pm 2.84$ \\
Konsumsi pakan $(\mathrm{g})$ & $160^{\mathrm{a}} \pm 5.77$ & $170^{\mathrm{a}} \pm 5.77$ & $160^{\mathrm{a}} \pm 5.77$ \\
\hline
\end{tabular}

Keterangan : Angka pada superskrip yang sama pada baris yang sama menunjukkan hasil yang tidak berbeda nyata

Tabel 2. Hasil Analisis Proksimat Pakan

\begin{tabular}{cll}
\hline No. & \multicolumn{1}{c}{ Parameter uji } & \multicolumn{1}{c}{ Hasil uji (\%) } \\
\hline $\mathbf{1}$ & Bahan Kering & 85.62 \\
$\mathbf{2}$ & Protein & 19.86 \\
$\mathbf{3}$ & Lemak & 3.32 \\
$\mathbf{4}$ & Air & 11.40 \\
$\mathbf{5}$ & Abu & 6.17 \\
$\mathbf{6}$ & Serat kasar & 2.85 \\
$\mathbf{7}$ & Karbohidrat & 41.20 \\
\hline
\end{tabular}

Pakan pada ke tiga jenis itik tersebut mengandung konsentrat, jagung, dedak padi, dan multi vitamin. Waktu pemberian pakan yang dilakukan juga sama, yaitu pada pukul 07.00 dan 16.00. Konsumsi pakan yang diberikan relatif sama, yaitu pada itik Magelang sekitar 170 g/ekor/hari, sedangkan pada itik Pengging dan itik Tegal, yaitu 160 g/ekor/hari.
Penggunaan pakan lokal berupa jagung dan dedak padi dengan pertimbangan bahan pakan tersebut murah, tidak bersaing dengan bahan pakan manusia, serta bermutu baik. Jagung dan dedak padi merupakan sumber energi bagi itik, sedangkan sumber protein diperoleh dari konsentrat, karena konsentrat merupakan 
campuran bahan pakan yang mengandung nilai gizi tinggi. Fungsi konsentrat adalah untuk melengkapi kekurangan gizi dari pakan lainnya (Wahyu, 2004). Darmono (2004) menyatakan bahwa konsentrat adalah pakan yang berasal dari biji-bijian dan mengandung protein yang cukup tinggi dan mengandung serat kasar kurang dari 18\%. Murtidjo (2002) menambahkan bahwa konsentrat diberikan dengan tujuan menambah nilai gizi pakan dan meningkatkan konsumsi pakan. Parakkasi (2006) menyampaikan bahwa konsentrat sumber protein dapat diperoleh dari hasil samping penggilingan berbagai biji-bijian, bahan pakan sumber protein hewani, dan hijauan sumber protein, sedangkan konsentrat sumber energi dapat diperoleh dari dedak dan biji-bijian seperti jagung.

Penggunaan jagung sebagai bahan pakan ditentukan oleh beberapa faktor, antara lain kandungan gizi yang terkandung sebagai alternatif dari bahan baku lain dan harganya relatif murah (Anggorodi, 2008). Pakan yang digunakan jagung, dimanfaatkan sebagai sumber energi dengan istilah energi metabolis. Jagung mengandung protein sebesar $8,5 \%$, tetapi penggunaan jagung sebagai pakan adalah untuk energi. Kegunaan energi jagung adalah dari pati yang mudah dicerna. Jagung juga mengandung 3,5\% lemak, terutama terdapat di bagian lembaga biji. Kadar asam lemak linoleat dalam lemak jagung sangat tinggi, sehingga dapat memenuhi kebutuhan itik, terutama pada itik petelur. Kandungan lemak tersebut mempengaruhi kadar kolesterol yang ada pada telur itik. Jagung juga merupakan sumber karbohidrat terbanyak dibandingkan pakan tambahan lainnya, dalam hal ini jagung berperan penting pada metabolisme karbohidrat, di mana peranan utama karbohidrat di dalam tubuh adalah menyediakan glukosa bagi sel-sel tubuh, yang kemudian diubah menjadi energi. Glukosa mempunyai peranan penting dalam metabolisme karbohidrat. Glukosa yang diserap dari pencernaan makanan di usus dibawa darah menuju ke seluruh tubuh. Glukosa dalam sitoplasma akan mengalami glikolisis, yaitu peristiwa pemecahan gula hingga menjadi energi (Tangendjaja dan Elizabeth, 2010)
Pakan yang diberikan selain jagung yaitu dedak padi. Dedak padi dengan produksinya yang tinggi, dapat melengkapi bahan pakan lain yang produksinya kurang sehingga harus dijaga pada proses penyimpanannya.

Persyaratan mutu standar pada pakan itik adalah sebagai berikut: protein berkisar $18-20 \%$, lemak 4-7\%, air 14\%, abu 14\%, dan serat $4-7 \%$ (Supriadi, 2011). Meningkatnya konsumsi serat menyebabkan laju aliran ransum meningkat dan sebagai akibatnya kolesterol di dalam ransum akan keluar melalui gerakan usus, sedangkan garam empedu akan diserap kembali ke dalam darah untuk diedarkan kembali sebagai kolesterol (Cai and Chen 2014). Pendapat ini didukung oleh Linder (2002), yang mengatakan bahwa serat kasar yang lain, yaitu pektin ternyata dapat mengikat asam empedu dan kolesterol, sehingga meningkatnya ekskresi asam empedu dan kolesterol dalam feses. Kemampuan dari fraksi serat kasar selulosa untuk mengikat kolesterol dalam saluran pencernaan sebesar empat kali berat molekul dari selulosa itu sendiri.

Hasil analisis menggunakan anova menunjukkan perbedaan nyata pada kadar vitamin A pada telur (Tabel 1), kadar vitamin A telur itik Pengging berbeda dengan itik Tegal, itik Magelang berbeda dengan itik Tegal, sedangkan pada vitamin A telur itik Pengging dan itik Magelang tidak berbeda nyata. Manajemen pakan yang diberikan pada ketiga jenis itik lokal tersebut adalah sama, maka kemungkinan perbedaan kadar vitamin A yang dihasilkan dari ketiga itik lokal tersebut disebabkan oleh potensi metabolik pada setiap itiknya. Pemberian pakan berupa jagung dapat memberi pengaruh terhadap kualitas kuning telur, dapat diketahui dalam jagung mengandung pigmen xanthophyll. Sujana et al. (2006) dalam penelitiannya menyatakan bahwa pakan berpengaruh langsung terhadap warna kuning telur itik, terutama pakan yang mengandung pigmen karotenoid, serta terdapat hubungan linear antara pigmentasi kuning telur dengan kandungan xanthophyll di dalam pakan.

Karotenoid merupakan suatu pigmen yang terdapat pada tanaman maupun hewan yang merupakan prekursor vitamin A. Bahan pewarna 
kuning telur adalah xanthophyll, suatu pigmen karotenoid yang terdapat dalam jagung. Zat warna xanthophyll dalam pakan merupakan senyawa yang paling berpengaruh terhadap warna kuning telur (Stadelman dan Cotterill, 2005). Semakin kuning warna yolk maka kandungan $\beta$-karoten yolk akan semakin tinggi pula. Hal ini sesuai dengan pendapat Sujana et al . (2006) bahwa kuning telur yang terang lebih banyak mengandung vitamin A daripada kuning telur yang berwarna pucat. Semakin banyak kandungan karotenoid dalam pakan yang diberikan itik petelur, maka kualitas karoten dalam kuning telur semakin baik. Hasil pengamatan menunjukkan terdapat perbedaan warna pada kuning telur seperti pada Gambar 1.

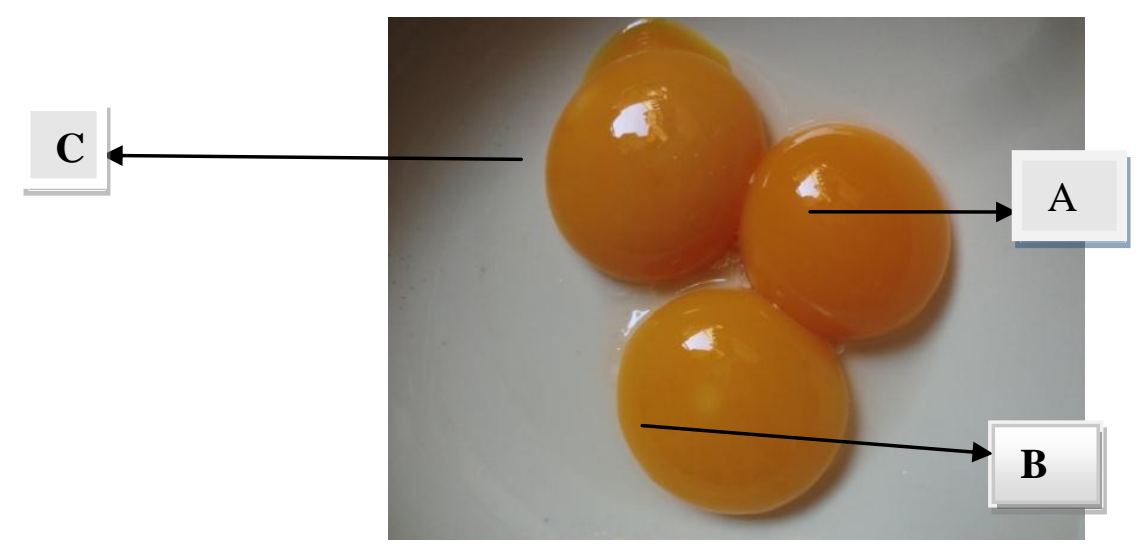

Gambar 1. Kuning telur (A) itik Magelang, (B) itik Tegal, (C) itik Pengging Berdasarkan warna kuning telur menujukkan terdapat perbedaan karoten dan vitamn A pada telur itik Magelang, itik Tegal dan itik Pengging.

\section{KESIMPULAN}

Berdasarkan hasil penelitian dapat disimpulkan bahwa kadar kolesterol terendah pada telur itik tegal, sedangkan kadar vitamin A tertinggi pada telur itik Pegging.

\section{DAFTAR PUSTAKA}

Anggorodi, H. R. 2008. Nutrisi Aneka Ternak Unggas. PT. Gramedia Pustaka Utama, Jakarta.

Azrimaidaliza. 2007. Vitamin A, Imunitas, dan Kaitannya dengan Penyakit Infeksi. Jurnal kesehatan Masyarakat. UNAND. Padang

Bappenas. 2009. Budidaya Ternak Itik, Proyek Pengembangan Ekonomi Masyarakat Pedesaan. http://. ristek. go. id. Akses 1 Januari 2015.

Cai J.S and Chen J.H.2014. The Mechanism of Enterohepatic Circulation ini the Formation of Gallstone Disease. J.Membr Biol. 247: $1067-1082$.
Darmono. 2004. Tata Laksana Usaha Sapi Kereman. Kanisius. Yogyakarta

Guyton, A. C. 2007. Textbook of Medical Physiology. 7th ed. W.B. Sunders Company. Philadelphia

Kritchevsky, D. 2006. Beta Caroten, Carotenoids, and the Prevention of Coronary Heart Disease. Journal Of Nutrition 129:5-8, 1999

Linder, C. M.. 2002. Nutritional Biochemistry and Metabolism. With Clinical Application. New york: Elsevier.

Montgomery, D.C. 2006. Design Analysis of Experiment, $6{ }^{\text {nd }}$. John Wiley \& Sons. Inc

Murtidjo, B. A. 2002. Mengelola Itik. Penerbit Kanisius. Jakarta

Nielsen, S. S. 2010. Introduction to The Chemical Analysis of Food. Chapman and hall. New York. USA 
Parakkasi, A. 2006. Ilmu Nutrisi dan Makanan Ternak Monogastrik. Universitas Indonesia Press. Jakarta

Poedjiadi, A., Supriyanti. 2005. Dasar-dasar Biokimia. UI Press. Jakarta.

Safitri, A. 2007. Komposisi Kimiawi Telur Itik Lokal Pada Berbagai Kualitas Pemberian Tepung dan Beluntas. Skripsi. Fakultas Peternakan IPB. Bogor

Stadelman, M. J., O. J. Cotterill. 2005. Egg Science and Technology. The AVI Publising Co., Inc., Westport Connecticut

Sudaryani, T. 2003. Kualitas Telur. Penebar Swadaya. Jakarta.

Sujana, E., Wahyuni, S., H. Burhanudin. 2006. Efek Pemberian Ransum yang Mengandung Tepung Daun Singkong, Daun Ubi Jalar, dan Eceng Gondok sebagai Sumber Pigmen Karotenoid Terhadap Kualitas Kuning Telur Itik Tegal. Jurnal Ilmu Ternak. Juni 2006. Vol. 6. No. 1,53-56

Suparyanto, A. 2005. Peningkatan produktivitas daging itik madalung melalui pembentukan galur induk. Disertasi. Sekolah Pascasarjana. Institut Pertanian Bogor.

Supriadi. 2011. Panduan Lengkap Itik. Penebar Swadaya. Jakarta.

Tangendjaja, B., W. Elizabeth. 2010. Limbah Tanaman dan prosuk Samping Industri Jagung untuk Pakan. Balai Penelitian Ternak. Bogor

Wahyu. J. 2004. IImu Nutrisi Ternak Unggas. UGM-Press, Yogyakarta. 